\title{
Collaborative Teacher Inquiry Into iPad Use in Grade 3 Classrooms: Mobilizing Knowledge Through a Long-term School-University Partnership
}

\author{
Ruth McQuirter Scott \\ Brock University
}

Donna Dortmans

Brock University

Cathy Rath

Halton Catholic District School Board

Nancy Meeussen

Halton Catholic District School Board

Jennifer Boin

Halton Catholic District School Board

\begin{abstract}
In this paper, we report on a longitudinal case study exploring Grade 3 teachers' implementation of iPads in the Language Arts classroom. A school-university partnership was formed based on a collaborative teacher inquiry model. We examined factors that shaped our collaboration. The project resulted in greater teacher sharing of iPad implementation strategies and growth in leadership skills among the teachers. A surprising finding was the degree of reciprocal learning about digital pedagogy that the university researchers experienced during the study and were able to share with their Pre-service Education classes. We emphasize the potential of school-university partnerships for narrowing the current gap between theory and practice in technologyenhanced learning.
\end{abstract}

Keywords: school-university partnership, collaborative teacher inquiry, knowledge mobilization, technology integration, iPads in education, school-based professional development

Ruth McQuirter Scott is Professor in the Faculty of Education at Brock University. Her research and teaching interests focus on technology in education, word study, and language arts instruction.

E-mail: rmcquirter@brocku.ca

Donna Dortmans is a sessional instructor in the Faculty of Education at Brock University. She teaches courses on assessment and is also a research assistant. 
Cathy Rath, Nancy Meeussen, and Jennifer Boin are elementary teachers in the Halton Catholic District School Board. They have an interest in the effective implementation of technology in all subject areas of their program. 


\section{Introduction}

Digital technology has the potential to reform classrooms in ways that were seldom considered before the beginning of the $21^{\text {st }}$ century. The fundamental role of teachers in technology-enabled classrooms is transformed from that of gatekeepers of knowledge to resource managers and design consultants (Knoble \& Wilbur, 2009). Digital devices such as iPads allow students to interact with multimodal texts, collaborate with peers on a local and global scale, and choose multiple ways to demonstrate their learning. Governments and school boards in Canada and the United States have made substantial investments in technology (Herold, 2015; People for Education, 2014). Technology implementation, however, has lagged in many schools and established teaching practices have not been challenged or transformed (Ertmer \& Ottenbreit-Leftwich, 2010; Herold, 2015). The gap between the potential of technology and its effective use in educational settings is an issue that needs to be addressed for students of all ages.

\section{Collaborative Teacher Inquiry}

Recent studies recommended that professional development in technology be schoolbased and adapted to the needs of the teachers and students in the school (Ertmer \& Ottenbreit-Leftwich, 2013; Fisher \& Rosenthal Tolisano, 2014). Hughes (2005) identifies collaborative teacher inquiry as an approach to professional learning that holds strong potential for technology integration. Teachers can focus on shared problems of practice (Palmisano, 2013) in a collegial setting where they can own the initiative instead of being confined by system-driven, top-down mandates (Cody, 2013). Credibility increases when individual teachers report on their classroom experiences with technology (Hobson, 2001) and an atmosphere of trust is established through which risk and uncertainty are valued and supported (Snow-Gerono, 2005). Collaborative teacher inquiry projects may also involve collaboration with academic researchers. The initiative may begin with the university, the board, or through joint needs and goals (School Board-University Research Exchange, 2014).

\section{School-University Partnerships}

Partnerships between school boards and universities have potential benefits for both groups. Working on their own without such partnerships, academic researchers may develop ideas solely from their research data while practitioners may draw conclusions exclusively from their interactions with students (Christianakis, 2010). By working together, academics and teachers can contribute their unique knowledge, skills, and perspectives to the inquiry.

Historically, school-university partnerships have been characterized by unequal power dynamics (Christianakis, 2010). University academics traditionally have created theories that practitioners (i.e., teachers) have implemented. This power differential has often led teachers to complain that theory is not relevant to practice. Randi and Corno (2007) agree that this perception may be valid "if teachers are handed particular theorybased practices, one-by-one, and asked to apply them, no matter what their teaching situations" (p. 341). True school-university partnerships require that all participants 
assume a "learning stance" (Literacy/Numeracy Secretariat, Ontario Ministry of Education, 2011), meaning that outside researchers or colleagues must visit a teacher's classroom as fellow learners rather than make judgments based on an external set of standards.

Trust in a collaborative relationship may need to build over time. Dana et al.'s (2001) report on professional development schools - involving a learning community of school and university personnel-showed that trust was a persistent problem in the early years; teachers were concerned that university professors "would not appreciate the work they do nor understand the complexities of their jobs "(p. 19). An atmosphere of "safety, trust, and care" (Clark, 2001) was established over time when teachers became equal partners in the research process and everyone was identified as a co-learner. Ertmer and Hruskocy (1999) described a multi-year school-university partnership designed to support technology integration in an elementary school. Trust was built by treating all team members as partners in the project, regardless of their role or rank. Teachers worked with university researchers to plan and implement all aspects of the project. Monthly meetings to identify changing needs and revise implementation strategies helped to keep lines of communication open. The study found an increase in teachers' levels of instructional and professional uses of technology, and a growth in students' confidence, self-esteem, and computer skills.

\section{Background to Project}

In the fall of 2013, two Grade 3 classroom teachers in an Ontario school board met with a former colleague and a university researcher from a nearby Faculty of Education to discuss the possibilities of a collaborative inquiry into iPad implementation in their Grade 3 classrooms. The former colleague and now retired teacher, Deborah (all names are pseudonyms), had connections with both the teachers, Candace and Natalie, and with Rita, the university researcher. Deborah had been a teaching partner with Candace and Natalie some years ago and, at the time of the meeting, was a participant in a technologyrelated research project with Rita. Candace and Natalie taught in the same school board, but in two different schools, and two different cities in the board. They initiated the contact because they were intrigued by Deborah's positive experiences with the technology-related research project mentioned above.

It was agreed that, once necessary permissions and ethical approvals were obtained, Rita and Deborah would visit the classrooms of Candace and Natalie at least once a month to provide feedback on their instructional use of iPads, primarily in language arts instruction. Rita and Deborah met with school board curriculum and research personnel to discuss the project and to ensure that the goals were consistent with the board's $21^{\text {st }}$ century student outcomes. The board approved the project and classroom visits commenced in mid-November 2013. After each year of the collaborative inquiry, Rita submitted an ethics protocol to both the university and the school board as well as a brief report to the research officer in the board regarding the previous year's work. New parental permission forms were collected each September.

In the spring of 2015, Natalie was seconded to an administrative position and left the classroom setting and the study. That fall, Candace's teaching partner, Jessica, asked to join the project, and Rita and Deborah continued to work in both classrooms when 
visiting the school. The project is currently in its third year, with Candace and Jessica as active participants. Over the course of the collaborative inquiry, a total of 31 visits have been made to the classrooms of Candace, Jessica, and Natalie, as well as five evening meetings held in Deborah's home to discuss the progress of the inquiry.

The initial project goals focused on developing a pedagogy for using iPads in language arts and were somewhat general in nature. We were aware, however, that detailed goals are not always articulated at the beginning of a collaborative teacher inquiry; teachers "remain flexible and open to learning who their students are and how best to teach them" (Cody, 2013, p. 68). As the inquiry progressed, Natalie and Candace (along with Jessica during Year 2 of the study) began to narrow their research focus. Natalie was committed to examining how she could set up a classroom that would allow students to display self-regulation (Mitra, 2010; Shanker, 2013) in their use of iPads. Candace and Jessica looked for evidence that the use of iPads went beyond engaging student interest and led students to delve more deeply into their learning. Rita shared her goals of identifying aspects of the school-university partnership that were helpful to the collaborative inquiry and those aspects that detracted from its effectiveness. She was also interested in learning about effective pedagogy for integrating iPads so that she could share these insights with her pre-service teacher education classes.

The research questions that evolved since 2013 were as follows:

1. What kind of classroom environment does promote student self-regulation in the use of iPads?

2. How does the use of iPads in the classroom influence student engagement and learning?

3. What factors and interactions in a school-university partnership facilitate effective collaborative teacher inquiry?

Although data were collected and analyzed for all three questions, it is the last research question that we address in this paper. The first two questions will be the focus of subsequent papers.

\section{Theoretical Framework}

Early in the study, Candace expressed her frustrations with attending typical workshops for teachers on the use of iPads: "So often we are just given a list of apps and told to 'make a pic collage' instead of being shown how to use it in the context of a lesson" (meeting notes, November 2013). Candace was identifying a paradigm for learning in which so-called "experts" provide information to passive students (in this case teachers during off-site professional development workshops), without helping them to transfer the new learning into their respective settings. In contrast, this study is based on the theoretical framework of situated learning (Lave \& Wenger, 1991), which views the learner as part of a social group that shares common goals and knowledge. Such groups are usually referred to as communities of practice (Lave \& Wenger, 1991). Knowledge is co-constructed through shared stories and joint problem-solving in authentic contexts (Hoadley, 2012). In a community of practice context, teachers would not be faced with the task of applying a 
list of iPad apps they saw demonstrated in a workshop, but would work with workshop facilitators and colleagues to discover and apply iPad pedagogy in their classrooms.

Collaborative teacher inquiry groups are examples of communities of practice, as the goals of learning are determined by the members who engage in ongoing knowledge building. Palmisano (2013) highlights the contrasts between collaborative teacher inquiry and traditional professional development approaches:

Moving from professional learning approached as the acquisition of methods and structures developed outside the classroom and the school, collaborative inquiry places educators in the role of actively constructing professional knowledge through treating their classrooms and schools as sites for investigation (Literacy in Learning Exchange, 2012).

Other knowledge-building communities, such as universities, can become part of the teacher community of practice, with each member contributing unique perspectives and backgrounds. Hoadley and Kilner (2005) explored the potential for technology to enhance communities of practice by enabling communication and shared knowledge among participants. Wenger, White, and Smith (2009) stressed that a community should not beDdefined by the particular technical domain in which it meets (e.g., a chat room or a blogging site), but should "find an identity that is defined by its learning rather than a specific tool" (p.189). In the current study, e-mail became an important tool for sharing insights and resources among participants when the researchers were not in the school setting. Nevertheless, our learning benefitted most from the interplay of classroom visits, email exchanges, conferences, and off-site meetings. Our school-university community of practice was enriched by the participants diverse perspectives and the combination of technology-enhanced (e.g., e-mail) and face-to-face interactions.

\section{Methodology}

We chose a qualitative case study method to report on this collaborative school-university inquiry project. Merriam (1998) identifies three characteristics as fundamental to a qualitative case study: (a) it is particularistic, meaning that it focuses on a "particular situation, event, program, or phenomenon" (p.29); (b) it is descriptive because the product is a "rich, 'thick' description of the phenomenon under study" (p.29); and (c) it is heuristic in its illumination of the reader's understanding of the phenomenon.

\section{Participants}

Candace, Natalie, and Jessica are experienced classroom teachers who initiated contact with Rita through their former colleague Deborah. Candace and Natalie have been teaching in the same board for 20 years and Jessica for 12. Deborah is a retired teacher who had previously served as an informal mentor to Candace and Natalie. She is now a sessional instructor at the same Faculty of Education where Rita has been employed as a professor for 24 years. Rita's teaching responsibilities at the university focus on language arts instruction for pre-service students in the elementary panel. Before joining the 
University, she was a teacher, a department head, and a curriculum consultant with a nearby school board.

When visiting classrooms, both Rita and her research assistant Deborah assumed the participant observer (Cresswell, 2008) role. Although they often sat at a table and made observational field notes, they also circulated around the classroom, interacting with students and frequently engaging in ongoing feedback with the classroom teacher. Rita and Deborah served as "critical friends" (Bambino, 2002; Costa \& Kallick, 1993) by giving verbal feedback both during class activities and in short meetings over lunch or recess. On more than one occasion, Deborah and Rita were invited to teach part of a lesson, and both researchers often joined in whole group discussions or worked with small groups of students.

\section{Data Collection Procedures}

Multiple forms of data were collected over the course of the project. Some of the data sources focused on the implementation of iPads in the classrooms. Rita and Deborah took observational field notes during each class. The notes described the teachers' pedagogical decisions, the students' reactions in a large group setting, and the students' performance during application tasks. As they interacted with students, Rita and Deborah often asked questions about the choices students were making in their assignments and their preferences for various iPad apps. They also took photos and videos of student work samples, as well as charts and other instructional materials prepared by Candace, Natalie, and Jessica.

Data related to the nature and effectiveness of the school-university partnership were also collected. Rita and Deborah made observational notes about the participants' interactions during in-class visitations, in-school planning sessions, and more informal evening meetings. E-mail correspondence was also used as a data source.

A questionnaire at the end of Year 1 asked Candace and Natalie to respond to questions about both iPad implementation and the nature of the school-university partnership in the collaborative inquiry. Questions related to the latter (the focus of this study) were as follows:

1. How helpful was it to be part of a collaborative inquiry group? In what ways have you grown professionally through this experience?

2. What personal goals do you have for technology-enhanced instruction in the next year of the project?

3. How could the collaborative inquiry team (Deborah, Rita, and fellow teachers in the project) help you meet these goals?

In Years 1 and 2 of the project Candace, Natalie, and Jessica made presentations at a variety of conferences, and their PowerPoint slides were collected as a data source.

\section{Data Analysis}

The data analysis was an inductive process (Cresswell, 2008) that began with a preliminary exploratory analysis of the multiple data sources, including observational 
field notes taken by both Rita and Deborah, e-mail exchanges among the participants, PowerPoint slides of conference presentations, Year 1 questionnaires, and student work samples. Following repeated readings of materials, data segments were coded as they related to both the pedagogy of iPad use by Natalie, Jessica, and Candace and to the dynamics of the school-university partnership. In this paper, we explored only the themes relevant to the research question: "What factors and interactions in a school-university partnership facilitate effective collaborative teacher inquiry?" Rita performed the data analysis, followed by a member check of themes and interpretations by Deborah, Jessica, Natalie, and Candace. The research officer in the school board also received a draft and was invited to offer comments. Internal validation was further strengthened by a longterm observation at the research site ( 2 years of observation at the time of writing) and triangulation of multiple data sources (Merriam, 1998).

\section{Findings and Reflections}

Candace and Jessica delivered a poster presentation at a major conference on technology in education. The title of their conference poster was "Practical Ideas for Integrating iPads Into a Grade 3 Classroom." They had expected just a few teachers to drop by their table, but discovered they had been allocated a prime location in the conference hall with room for numerous rows of chairs. Their PowerPoint slides, which had been designed as talking points for brief one-on-one conversations, became the basis for an instant workshop presentation to over 40 conference delegates. After the presentation, Candace sent the following e-mail to Rita, Deborah, and Jessica:

You should have seen our faces when we saw the booth they put us in! We had to adjust our presentation right before it started because all these people showed up and parked themselves on the furniture-they were there for the long haul, so we went slide by slide and did a formal presentation. We had a few come up and talk to us after and it sounded like they liked it and found it helpful. (e-mail correspondence, May 7, 2015.)

Candace's e-mail reflects three of the themes derived from multiple data sources: building trust, breaking down silos, and teachers as leaders. Another theme that emerged from the data was reciprocity of learning, often present in Rita's and Deborah's stories of teaching pre-service Education classes.

\section{Building Trust}

It was not easy for Candace, Natalie, and Jessica to describe their use of iPads to conference participants in a setting quite different from their classrooms. When Rita first suggested they had valuable insights to share more widely, their reaction was tentative. Rita invited them in the first year of the project to present at a Technology Showcase for local teachers and pre-service students at the University. Candace's response was: "I will talk about it more with Natalie. I could maybe be persuaded..." (e-mail correspondence, November 11, 2013). As the conference approached, Candace wrote: "Natalie and I are in full panic mode... I sure hope we do OK - I am getting really nervous about it" (e-mail 
correspondence, May 7, 2014). How did they move from this state of insecurity to one in which they trusted their practice and were comfortable sharing their findings in a large venue?

Several factors contributed to the development of trust between the school and university partners. On one hand, our school-university community of practice had the advantage of building on pre-existing positive relationships among Natalie, Candace, and Deborah. When Jessica joined the study, she was already Candace's colleague and teaching partner. On the other hand, Rita was unknown to the classroom teachers, apart from her published work in language arts. Candace admitted early that she was intimidated by the fact that resources authored by Rita were in her classroom and hoped that Rita would not judge her for failing to use academic jargon in her conversations. Candace described herself as "just a teacher." Natalie seemed more comfortable with Rita's occasional use of academic terms, as she had worked for a time as an itinerant resource teacher, read widely on educational issues, and had some experience presenting to colleagues in her school board. Deborah's presence was extremely valuable because she had previously collaborated with Rita on a research project and could report her positive experience to the teachers. The preliminary meeting Deborah hosted in her home also helped everyone to relax.

During the many classroom visits, the feedback given by Deborah and Rita was constructive and specific. Acting as critical friends, they were able to point out dynamics that may not have been apparent to Natalie, Jessica, and Candace in the busyness of their classrooms. On occasion, it was necessary to point out the positive aspects of a lesson that the teacher had thought was unsuccessful. After one such lesson, Deborah responded in an e-mail to Candace:

Don't be so hard on yourself. It was great! I learned so much talking to the kids about what they learned; a few prompts and they were able to tell me what they were doing. They loved the activity, and they really are so curious about their learning. Your natural talent as a teacher shines through (e-mail correspondence, June 11, 2014).

These affirmations are important in building a collaborative community. Snow-Gerono (2005) emphasized the importance of a support network when teachers examine their pedagogy: "Questioning personal practice can be a difficult and uncomfortable position for teachers. However, when people are supported and assisted with their questions, inquiry becomes a collaborative, more attainable experience" (p. 247).

The gulf between the traditional university orientation to theory and the school emphasis on practice dissipated during our collaborative inquiry, which not only built trust among the members of the group, but also helped Natalie, Jessica, and Candace to appreciate their teaching. On numerous occasions, Rita and Deborah pointed out the skillful use of instructional strategies that facilitated differentiated instruction in technology, or that supported the "Gradual Release of Responsibility" model (Pearson \& Gallagher, 1983) underlying their lesson planning. Although these strategies were simply part of the instructional repertoire of these experienced teachers, the teachers seemed pleased to have their skills acknowledged. 
Rita and Deborah frequently followed up on visits with e-mails that recommended practical resources, websites, and blog posts that either addressed a concern or might enrich the lesson they had seen. Rita shared a list of iPad apps for teaching poetry and Candace replied: "Love, love, love this site!!! I just said to Jessica the other day that I feel we are on a plateau, and we need some new ideas to try" (e-mail correspondence, April 9, 2015). Jessica added: "I may actually enjoy working with poetry using these! Thanks for thinking of us!!!" (e-mail correspondence, April 9, 2015). In an e-mail message, Deborah also captured the trusting relationship that developed between the school and university partners by the end of the first year:

This has been a wonderful experience, and we so appreciate that you trust us to be part of the reality of everyday teaching. It is a rare thing to have the rapport we have developed this year, eating, drinking, laughing, and sharing... Rita and I could never have learned what we did without your openness and honesty" (e-mail correspondence, June 11, 2014).

\section{Breaking Down Silos}

The systemic isolation of teachers from one another is often identified as a stumbling block to the integration of technology. Hobson (2001) describes the architecture of schools as "cellular patterns separating each one from the others" (p. 174). In addition to being physically divided by architecture, Hobson argues that teachers are also prevented to collaborate due to their distinct timetables, supervision duties, grades, and subject areas.

In Year 1 of the study, Natalie was new to her school and taught in a portable classroom. Opportunities for her to share her passion for technology with fellow teachers were limited. The visits from Deborah and Rita allowed her to have the "critical friends" she sought in the initial meeting of the group. Due to lack of supply teacher coverage Natalie was not able to visit Candace and Jessica's classrooms, but Rita and Deborah often shared what they had observed during the classroom visits. Evening meetings of the group provided rich conversations about what each teacher had tried recommended professional readings and apps, as well as insights into the intricacies of managing classroom dynamics when integrating technology.

Candace and Jessica benefitted from teaching next door to one another. They shared planning time and were able to move back and forth during a lesson to problemsolve and make suggestions. This ability to break out of the silo effect allowed them to learn on-the-go, and addressed one of Candace's reasons for joining the collaborative inquiry: "When you're on your own, you're not learning anything" (meeting notes, November 15, 2013).

The workshops and conference presentations Jessica, Natalie, and Candace, made over the first two years of the project helped them to escape from the silo effect as well. They received positive feedback on their work from fellow teachers and were able to attend other conference sessions on technology-enhanced instruction. In one particular case, Jessica and Candace returned from a teacher-led workshop on iPad use in mathematics and were thrilled by the practical strategies and resources they had acquired. 


\section{Teachers as Leaders}

Over the course of the study, Natalie, Jessica, and Candace showed growing leadership on several fronts. Their willingness to share their successes and challenges with iPad implementation was welcomed by teachers and pre-service students at workshops and conferences. They presented at a Technology Showcase attended by teachers from surrounding school boards and pre-service teachers. They also were accepted as presenters at two major technology-in-education conferences for teachers, administrators, and technology companies. While Rita and Deborah provided input on proposals and PowerPoint slides, and attended the sessions as supportive observers, the experts were clearly Natalie, Candace, and Jessica. Curriculum leaders in their school board attended one of their conference sessions and subsequently invited them to share their findings with senior administrators in the school system. In addition to informing K-12 teaching, Natalie, Candace, and Jessica also enriched Rita's and Deborah's classes at the Faculty of Education. Rita and Deborah frequently used their observations from the research sites to highlight technology-enhanced learning in their pre-service courses. After the first year of the study Candace reflected:

I have grown a lot from this experience. As an experienced teacher, you can get stuck in a rut and not try new things in the classroom. This year, I have come out of my comfort zone and really tried many new things within my classroom and outside of my classroom. I am not much of a public speaker, but having to talk to groups of teachers at the conference made me more comfortable to speak in front of others (e-mail correspondence, June 2014).

Natalie and Jessica continue to downplay the groundbreaking nature of their contributions to iPad pedagogy. When Rita shared with them the initial draft of this paper for validation of themes, Natalie declared: "You have made me look like I know what I'm doing" (e-mail correspondence, September 02, 2015). Jessica added: "You've captured our journey very well, and I think we're all better teacher learners because of these experiences we've shared"' (e-mail correspondence, August 316, 2015).

\section{Reciprocity of Learning}

When Deborah approached Rita in 2013 indicating that Natalie and Candace were interested in working with her, Rita was open to the idea. She had a particular interest in linking theory with practice and was keen to see how technology was being implemented in elementary classrooms. At the initial meeting, everyone shared their hopes for the project. Rita's hope was simple: "I want to see good teachers using technology" (meeting notes, November 6, 2013). She also hoped that her preliminary investigations into apps for literacy learning would be useful to Candace and Natalie. What Rita did not anticipate was that her teaching practice at the Faculty of Education would be enriched by this collaborative inquiry. Moreover, many of her students reported using the shared resources and strategies in their teaching placements. 
As Rita observed Natalie, Candace, and Jessica using iPads in Language Arts instruction, she began to see links between theory and practice with respect to technology-enhanced learning. She applied frameworks such as the "Substitution Augmentation Modification Redefinition Model" (Puentedura, 2013; Schrock, 2015) to explore how the teachers in the study used technology in their lessons. Did teachers' use of digital applications enhance student learning through substitution or augmentation of traditional practice, or did they transform learning through uses that could be classified as modification or redefinition of previous modes of learning? Rita also examined the professional growth of Candace, Jessica, and Natalie through the lens of "Technological Pedagogical and Content Knowledge," a framework that explores the interplay of technological, pedagogical, and content knowledge in teacher professional learning related to technology (Mishra \& Koehler, 2006). As an academic, she realized how valuable it was to have a research site in which emerging theory could be linked with practice.

Beyond connecting theory and practice as it relates to technology, Rita was also able to incorporate many general pedagogical concepts regarding literacy into her classes at the Faculty of Education. By using specific examples from visits to her research sites (while respecting all ethical protocols regarding anonymity), she was able to illustrate abstract concepts for her students. For example, when discussing how to organize a Literacy Block that included various instructional formats, Rita described Natalie's procedure for using a combination of learning centres, guided reading, independent reading, and online resources. Slides of Natalie's classroom — taken before class began and without students - showed how the arrangement provided for collaboration in small groups, teacher-student conferences, independent work, and whole class discussions. Rita was able to explain the "Gradual Release of Responsibility Model" (Pearson \& Gallagher, 1983) by describing how Candace and Jessica introduced a new iPad app to their classes by moving from teacher modeling, to shared creations by the whole class, to individual or paired work. An example of differentiated instruction presented itself when a child who struggled with writing nevertheless conveyed emotions in a poster about social justice through the use of "emojis" (often used in texting and e-mails to convey emotions) rather than traditional text. When Rita's students were learning how to write lesson plans, Rita modeled a lesson she had seen that week in Candace's class, and systematically deconstructed it using the template for a lesson plan. In each of these instances, Rita's lectures became relevant and current because of her observations and participation in K-12 classrooms.

Rita's students also benefited from digital resources she encountered in the schools. One that her students loved was the web-based application "Kahoot" (Kahoot.com). This tool allows a teacher to create online quizzes that use background music, timed responses, and team play to create tension and excitement. Rita had been amazed by the engagement of Grade 3 students in Jessica's and Candace's classes when they played Kahoot to review the usually dry topic of non-fiction text features. Rita recounted this experience to her own classes, then had them participate in a Kahoot quiz about literacy terms. Rita's students, too, reacted with tremendous enthusiasm. Many students reported using this tool successfully in their subsequent teaching practicum.

One iPad app, in particular, led to a series of exchanges between Rita and Candace. Rita observed Candace using the app "Pic Collage" in her class as a way for 
students to represent what they had learned about the Native American leader Chief Joseph. Pic Collage provides for the creation of photo collages accompanied by text and sound. Rita described this lesson to her Language Arts classes and had her students use the app to illustrate haiku poems they had written based on Col. Chris Hadfield's tweets sent from the International Space Station. Each tweet described a location on Earth he observed from space. When Rita recounted this lesson to Candace, she taught her Grade 3 students the haiku poetic form, creating haikus and Pic Collages to synthesize what they had learned about Chief Joseph. Rita sent the following comment to Candace: "You and I need to write about this incredible back and forth learning from such diverse age groups" (e-mail correspondence, March 5, 2014).

Finally, this collaborative inquiry project became a model for Rita's students as they embarked upon a collaborative inquiry of their own for a major course assignment. Rita shared the following with Natalie, Jessica, and Candace:

When we get together, I will tell you how I used our project with my classes this week to explain collaborative inquiry and problems of practice. They are identifying areas of Language Arts to investigate further based on their first placement experiences. I think it was helpful for them to hear that experienced teachers are never satisfied with their practice and still find areas in which they see the need to learn more (e-mail correspondence, January 9, 2014).

Whether it was theories of technology-enhanced instruction, general pedagogical concepts, specific iPad or web-based resources, or the nature of communities of practice, Rita and her students benefitted greatly from her participation in this project.

\section{Discussion}

The gap between theory and implementation of technology-enabled instructional practices is a serious concern for educators. In this study we explored the potential for a school-university partnership to mobilize and build knowledge related to iPad implementation in Grade 3 classrooms. Based on the principles of situated learning, we established a school-university community of practice in the form of a collaborative teacher inquiry to address this issue. Consistent with other communities of practice, we engaged in joint goal setting and problem-solving. Our growing knowledge of effective iPad pedagogy was co-constructed in an authentic setting over time.

We paid careful attention to building trust between the teachers in the study and the university researchers by positioning each person as a learner. Over a period of two years (and as we continue), the three teachers (Jessica, Candace, and Natalie) and the university researchers (Rita, and Deborah) experimented with approaches to using digital technology in the classroom, reflected on lessons, and shared resources. As a result of these interactions, Candace, Jessica, and Natalie grew as leaders in the area of iPad implementation while Rita's and Deborah's pre-service students benefited from the resources and pedagogical approaches their instructors brought back to their classes. In the traditional model of school-university partnerships, the assumption is that the university researchers possess knowledge that is imparted to the school participants 
(Christianakis, 2010). In this paper, we showed that schools can provide rich insights to universities and influence generations of future teachers.

Even though this school-university community of practice was characterized by eager learners and a multi-year time frame, it was not without challenges. The silo effect was only partially overcome. Candace and Jessica in the second year of the project were fortunate to be positioned next door to one another and had a daily common planning time. As a result, they were able to collaborate on lesson planning and drop in on one another's classes to share insights and solve problems. Natalie, however, was in a portable in a different school, and there was no money for supply coverage for her to visit the classrooms of Candace or Jessica. In both schools, teachers in the study had limited opportunity to share their growing expertise with immediate colleagues. Much of their impact on other teachers came through conference and workshop presentations to those in attendance. It was also challenging to link this study with other technology initiatives in the school board, although Natalie and Candace were able to share their findings with administrators and participants in other technology-related studies on a few occasions.

The second area of concern was logistical in nature. While Deborah and Rita acted as "critical friends" in the classroom and gave feedback to Jessica, Natalie, and Candace during the lessons and through follow-up e-mails, they often wished they could meet with the teachers soon after each lesson to engage in more in-depth discussions and to plan for future lessons. However, the teachers often had supervision duties following the observation time and were not able to engage in immediate in-depth discussions.

The following recommendations are geared toward building school-university partnerships to foster the implementation of digital technology:

1. School-university partnerships should be based on the premise that all participants are learners. Power imbalances can be mitigated by ensuring that school participants are seen as fellow researchers and are involved in the design and implementation of the study.

2. University personnel should use their contacts and resources to build leadership skills among teachers in their study. Such capacity building will help to transfer the knowledge acquired to a wider audience of educators.

3. Administrators should assist teachers involved in a collaborative inquiry to meet regularly, whether through joint planning time, the positioning of classrooms, or secured funding to visit other sites.

4. Universities and school boards should collaborate so that school-based initiatives can be shared board-wide and resources provided to support teachers committed to professional growth.

5. Whenever possible, school-university partnerships should be maintained over time to facilitate the building of trust and to enable deeper engagement in longterm changes in practice.

\section{Moving Along}

As our collaborative teacher inquiry nears the end of its third year, we continue to evolve in our goals and procedures. Rita and Deborah are beginning to book regular feedback

Brock Education Journal, 25 (1), Fall 2015 
meetings with Candace and Jessica during their planning time and immediately after each classroom visit. This allows for reflection on the lesson and future goal setting. Jessica and Candace are interested in expanding their iPad use to their social studies program and using an inquiry approach as the students explore social studies topics. They have been given release time to work with Rita and Deborah to plan this inquiry unit. Natalie returned to a classroom position mid-year, following her secondment as an administrator, and will return to the study in the fall. All three teachers have been involved with Deborah and Rita in writing papers about their iPad use, thereby sharing their insights more widely. The story continues. 


\section{References}

Bambino, D. (2002). Critical friends. Educational Leadership, 59(6), 25-27.

Christianakis, M. (2010). Collaborative research and teacher education. Issues in Teacher Education, 19(2), 109-125.

Clark, C. (2001). Good conversation. In C. Clark (Ed.), Talking shop: Authentic conversation and teacher learning (pp. 172-182). New York, NY: Teachers College Press.

Cody, A. (2013). Two ways to lead. Educational Leadership, 71(2), 68-71.

Costa, A., \& Kallick, B. (1993). Through the lens of a critical friend. Educational Leadership, 5(2), 49-51.

Cresswell, J. (2008). Educational research: Planning, conducting, and evaluating quantitative and qualitative research. Upper Saddle River, NJ: Pearson.

Dana, N. F., Silva, D. Y., Gimbert, B., Nolan, J., Zembal-Saul, C., Tzur, R., Mule, L. (2001). Developing new understandings of PDS work: Better questions, better problems. Action in Teacher Education, 22(4), 15-27.

Ertmer, P., \& Hruskocy, C. (1999). Impacts of a university-elementary school partnership designed to support technological integration. Educational Technology Research and Development, 47(1), 81-96.

Ertmer, P., \& Ottenbreit-Leftwich, A. (2010). Teacher technology change: How knowledge, confidence, beliefs, and culture intersect. Journal of Research on Technology in Education, 42(3), 255-284.

Ertmer, P., \& Ottenbreit-Leftwich, A. (2013). Removing obstacles to the pedagogical changes required by Jonassen's vision of authentic technology-enabled learning. Computers \& Education, 64, 175-182. doi:10.1016/j.compedu.2012.10.008

Fisher, M. L, \& Rosenthal Tolisano, S. (2014). Digital masters: Becoming a blogmaster, annotexter, or web curator. In H. Hayes Jacobs (Ed.), Mastering digital literacy (pp. 5-26). Bloomington, IN: Solution Tree Press.

Herold, B. (2015, June 10). Student-centered, technology-driven instruction remains elusive for most [Web log post]. Retrieved from http://www.edweek.org/ew/articles/2015/06/11/why-ed-tech-is-not-transforminghow.html?cmp=ENL-EU-NEWS1

Hoadley, C. (2012). What is a community of practice and how can we support it? In D. H. Jonassen \& S. M. Land (Eds.), Theoretical foundations of learning environments (Second ed., pp. 287-300). New York, NY: Routledge.

Hoadley, C., \& Kilner, P. G. (2005). Using technology to transform communities of practice into knowledge-building communities. SIGGROUP Bulletin, 25(1), 3140 . 
Hobson, D. (2001). Learning with each other: Collaboration in teacher research. In G. Burnaford, J. Fisher, \& D. Hobson (Eds.), Teachers doing research: The power of action through inquiry (pp. 173-191). Mahwah, NJ: Erlbaum.

Hughes, J. (2005). The role of teacher knowledge and learning experiences in forming technology-integrated pedagogy. Journal of Technology and Teacher Education, 13(2), 277-302.

Knobel, M., \& Wilber, D. (2009). Let's talk 2.0. Educational Leadership, 66(6), 20-24.

Lave, J., \& Wenger, E. (1991). Situated learning: Legitimate peripheral participation. New York, NY: Cambridge University Press.

Literacy and Numeracy Secretariat, Ontario Ministry of Education. (2011, October 14). Lucy West: Insights into effective practice-Talk into practice [Video file]. Retrieved from https://www.youtube.com/watch?v=syPbBsWK05Q

Merriam, S. (1998). Qualitative research and case study applications in education. San Francisco, CA: John Wiley.

Mishra, P., \& Koehler, M. (2006). Technological pedagogical content knowledge: A framework for teacher knowledge. Teachers College Record, 108(6), 1017-1054.

Mitra, S. (2010, July 28). The child-driven education [Video file]. Retrieved from http://www.ted.com/talks/sugata_mitra_the_child_driven_education

Palmisano, M. (2013, May 18). Collaborative inquiry differs from traditional professional development [Web log post]. Retrieved from http://www.literacyinlearningexchange.org/collaborative-inquiry-differs

Pearson, P.D., \& Gallagher, M. (1983). The instruction of reading comprehension. Contemporary Educational Psychology. 8, 317-344.

Chen, B., Gallagher-Mackay, K., \& Kidder, A. (2014). Digital learning in Ontario schools. Toronto, ON: People for Education. Retrieved from http://www.peopleforeducation.ca/document/digital-learning-in-authorsontarioschools-2014/

Puentedura, R. (2013, October 25)). SAMR: A contextualized introduction [Web log post]. Retrieved from http://www.edweek.org/ew/articles/2015/06/11/why-edtech-is-not-transforming-how.html?cmp=ENL-EU-NEWS1

Randi, J., \& Corno, L. (2007). Theory into practice: A matter of transfer. Theory into Practice, 46(4), 334-342. doi:10.1080/00405840701593923

School Board-University Research Exchange. (2014, November 23). Models of collaboration [Video file]. Retrieved from http://www.surenetwork.ca/models-ofcollaboration/

Schrock, K. (2015). Resources to support the SAMR Model. In Kathy Schrock's guide to everything. Retrieved from www.schrockguide.net/samr.html

Shanker, S. (2013). Calm, alert and learning: Classroom strategies for self-regulation. Toronto, ON: Pearson Canada. 
Snow-Gerono, J. (2005). Professional development in a culture of inquiry: PDS teachers identify the benefits of professional learning communities. Teaching and Teacher Education, 21(3), 241-256.

Wenger, E., White, N., \& Smith, J. (2009). Digital habitats: Stewarding technology for communities. Portland, OR: CPsquare. 